Meta

Journal des traducteurs

Translators' Journal

\title{
Crowdsourcing Translation in Contemporary China: An Inspiring Perspective of Translation in the Web 2.0 Age
}

\section{Yixin Cao}

Volume 60, numéro 2, août 2015

$60^{\mathrm{e}}$ anniversaire. Les horizons de la traduction : retour vers le futur $60^{\text {th }}$ Anniversary. Translation's Horizons: Back to the Future

60mo aniversario. Los horizontes de la traducción: regreso al futuro

URI : https://id.erudit.org/iderudit/1032867ar

DOI : https://doi.org/10.7202/1032867ar

Aller au sommaire du numéro

Éditeur(s)

Les Presses de l’Université de Montréal

ISSN

0026-0452 (imprimé)

1492-1421 (numérique)

Découvrir la revue

Citer ce document

Cao, Y. (2015). Crowdsourcing Translation in Contemporary China: An Inspiring Perspective of Translation in the Web 2.0 Age. Meta, 60(2), 316-316. https://doi.org/10.7202/1032867ar d'utilisation que vous pouvez consulter en ligne. 


\title{
Crowdsourcing Translation in Contemporary China: An Inspiring Perspective of Translation in the Web 2.0 Age
}

\author{
Yixin CaO \\ City University of Hong Kong, Hong Kong \\ yxcao5-c@my.cityu.edu.hk
}

With the popularization of internet, the development of computer science, and the democratization of information, internet crowdsourcing and crowdsourcing translation has become increasingly popular. Crowdsourcing translation is broadly applied in a variety of online communities, including: social networks, informative websites, movie and animation fansubbing groups, humanitarian organizations (language-learning websites, and so on. As crowdsourcing translation has accumulated attention from the professional circle, it also aroused controversial debates on copy-right issues, as well as quality problems and evaluation standards. To a large extent, crowdsourcing translation shares the main features with internet crowdsourcing: voluntary participation, crowdsourcers' multiple identities, and in most cases, translation for free.

This research aims at investigating the history and analyzing the features of crowdsourcing translation in nowadays China, so as to expound how the internet has democratized the production and consumption of translation, how the subjects involved in crowdsourcing translation are dynamically interrelated to each other, and how the concepts and culture of translation have changed with the decentralization of the translation power structure.

To start with, China is a monolingual country without neither a mature economic system nor a strictly regulated translation industry. Thus although crowdsourcing translation has existed for about one decade, and has immensely developed in scale and popularity, the crowdsourcing spirit stayed the same: non-profit, personal goals prevail money. Also, in Chinese crowdsourcing communities, the aim for translation is majorly introducing in foreign cultural products. And in the most cases, the source language is English, the largest second language of Chinese people since the opening up policy, an indication of cultural hegemony. Further, in China, a country exerts a harsh media censorship, the utopian-like crowdsourcing communities at their early stage are in fact, protesting discourses against the official ideology.

Yixin Cao is a PhD candidate at the Department of Linguistic and Translation, City University of Hong Kong. She got both her BA and MA degrees in Literature and Literature Criticism at the Department of English, Sun Yat-Sen University, China. Her research interests include critical theories, translation studies, contemporary Chinese studies, youth culture and sub-culture. Currently she is exploring the user-generated translation and crowdsourcing translation phenomenon in China, which she believes, is an inspiring revolution of translation in the Web 2.0 age in every aspect. Her most recent article, Translation Crowdsourcing and the Transmutation of Translator's Subjectivity was publish in 2015 in the East Journal of Translation. 